\title{
Diagnostic accuracy of protected catheter sampling in ventilator- associated bacterial pneumonia
}

\author{
F. Bregeon*, L. Papazian ${ }^{\dagger}$, P. Thomas ${ }^{\star}$, V. Carret ${ }^{\dagger}$, L. Garbe ${ }^{\S}$, P. Saux ${ }^{\Uparrow}$, M. Drancourt ${ }^{\#}$, J-P. Auffray
}

Diagnostic accuracy of protected catheter sampling in ventilator-associated bacterial pneumonia. F. Bregeon, L. Papazian, P. Thomas, V. Carret, L. Garbe, P. Saux, M. Drancourt, J-P. Auffray. C ERS Journals Ltd 2000.

ABSTRACT: The aim of this study was to assess the accuracy of protected telescoping catheter performed using: 1) protected distal aspiration, or 2) protected minibronchoalveolar lavage for the diagnosis of ventilator-associated bacterial pneumonia.

Twenty-seven patients who died after receiving mechanical ventilation for at least $72 \mathrm{~h}$ were included in a comparative prospective post-mortem study. The two microbiological sampling procedures were performed immediately after death. Surgical pneumonectomies and biopsies were performed within $30 \mathrm{~min}$ of death at the bedside for histological examination. The results of the two techniques were compared with histological post-mortem lung examination or biopsies.

Histological examination of the parenchyma showed signs of pneumonia in 14 cases. Lung tissue culture was positive in nine of these 14 cases. When ventilator-associated bacterial pneumonia was defined by the association of histological signs and positive lung tissue culture the sensitivity was $\mathbf{7 8 \%}$ for both sampling techniques, specificity was $86 \%$ for mini-bronchoalveolar lavage and $100 \%$ for protected distal aspiration (at a threshold of $1 \times 10^{3} \mathrm{cfu} \cdot \mathrm{mL}^{-1}$ ).

Both techniques protected the distal aspiration and mini-bronchoalveolar lavage, and provided good specificity with an acceptable sensitivity for the diagnosis of ventilator-associated bacterial pneumonia.

Eur Respir J 2000; 16: 969-975.
*Laboratory of Physiology, UPRES EA 2201, Université de la Méditerranée, ${ }^{\dagger}$ Medical I.C.U., Hôpitaux Sud, ${ }^{\dagger}$ Thoracic surgery, Hôpitaux Sud, ${ }^{\S}$ Laboratory of Pathology, Hôpitaux Sud, "MedicoSurgical I.C.U., Hôpitaux Sud, and ${ }^{\#}$ Laboratory of Microbiology, Hôpitaux Sud, Marseille, France.

Correspondence: L. Papazian, Réanimation Médicale, Hôpital Sainte-Marguerite, 13274 Marseille Cedex 9, France, Fax: 33 491745435

Keywords: Diagnostic, evaluation, histology, mechanical ventilation, nosocomial, pneumonia

Received: January 272000

Accepted after revision July 122000

This study was supported by the Assistance Publique Hôpitaux de Marseille, France.
Nosocomial bronchopneumonia occurs frequently in patients requiring mechanical ventilation. It has a high incidence when either clinical or histological criteria are used [1-6]. In ventilated patients, clinical criteria are usually regarded as unreliable because many noninfectious processes can mimic pneumonia or because true cases of pneumonia do not always provide clinical evidence. Therefore, in order to identify cases of ventilatorassociated bacterial pneumonia and to determine the bacteria responsible for it, microbiological bronchial sampling techniques are required. An invasive strategy based on bronchoscopic sampling has been proposed by some authors [7-8] but this is time consuming, expensive and can worsen the patients' respiratory status. Moreover, some studies have highlighted the lack of sensitivity and/ or specificity $[3,6,9]$. A noninvasive strategy based on blind methods has also been proposed [9-11]. Among noninvasive sampling methods, some authors have proposed a protected telescoping catheter inserted blindly into the respiratory tract in order to avoid contamination of the sample with pathogens from the upper tracheobronchial tree $[12,13]$. A protected telescoping catheter can be used in two ways, either by simple distal protected aspiration or instillation of sterile saline, i.e. protected mini-bronchoalveolar lavage. There is no previous study that evaluates protected distal aspiration using histology as the reference method, and only one group has evaluated mini-bronchoalveolar lavage $[13,14]$.

The aim of this work was to evaluate blind protected distal aspiration and blind mini-bronchoalveolar lavage using lung histology and tissue culture as reference tests for the diagnosis of bacterial ventilator-associated pneumonia.

\section{Materials and methods}

\section{Patients}

Nonimmunosuppressed patients who died after receiving mechanical ventilation for at least $72 \mathrm{~h}$ in the Polyvalent ICU of Sainte-Marguerite Hospital in Marseille, France (October 1994-December 1997) were included in the study if: 1) ventilator-associated bacterial pneumonia was suspected, 2) death occurred during laboratory working hours, and 3) the relatives gave written consent (second period of the study). Within 15 min of death, the two microbiological sampling techniques were performed. Thereafter, either entire lung removal or blind lung biopsies were performed. 
The following variables were recorded prospectively on admission: age, sex, severity score (APACHE II score) [15], severity of underlying condition according to the criteria of MCCABE and JACKSON [16] and reason for admission to the ICU. A radiological classification using the WeINBERg et al. [17] score was also recorded.

The presence or absence of a clinical diagnosis of ventilator-associated bacterial pneumonia was evaluated prospectively prior to death. A complete clinical picture of pneumonia was defined as the presence of all the following criteria: chest radiograph showing a new and persistent infiltrate consistent with pneumonia, purulent sputum, elevated temperature $>38.3^{\circ} \mathrm{C}$ or white blood cells (WBCs) count $\geq 10,000$ or $\leq 1,500 \cdot \mathrm{mm}^{3}$ and alteration of gas exchange. A Clinical Pulmonary Infection Score (CPIS) was calculated during the $24 \mathrm{~h}$ preceding death according to the criteria of PugIN et al. [18].

The study was approved by the authors Institutional Review Board. In the first period of the protocol (October 1994-March 1995) whole lung removal for histological examination was undertaken according to current French legislation which allowed the removal of organs for scientific research barring express opposition by the patient before death (Law No. 76-1181, December 22, 1976, followed by Statutory Order No. 78-501, March 31, 1978, and the Implementation Order dated April 4, 1978). Following a change in the legislation, the study was suspended for 1 yr. In the second period (April 1996December 1997), lungs were sampled and studied after family members had given written informed consent according to the new legislation (Law No. 94-653, July 29, 1994 Art. L. 671-9.). Thereafter, family members consented only for biopsies but not for total lung removal. In total, 20 patients were included during the first period, and 7 during the second period.

\section{Respiratory sampling}

The two sampling techniques were performed immediately after death without discontinuing mechanical ventilation. The results of the semi-quantitative analysis of sputum allowed calculation of the CPIS score. In order to avoid the spread of diluted secretions resulting from minibronchoalveolar lavage, protected distal aspiration was performed first, followed by lavage. Protected distal aspiration was performed via a double polyethylene catheter (Combicath $^{\mathrm{TM}}$; Plastimed, Saint-Leu-La-Foret, France), according to the technique described by РнAм et al. [12]. Mini-bronchoalveolar lavage was performed using a double polyethylene catheter (Combicath ${ }^{\mathrm{TM}}$; Plastimed, Saint-Leu-La-Foret, France) according to the technique described by Rouby et al. [13]. A 20-mL aliquot of normal saline was injected via the internal catheter and at least 2-mL was aspirated for microbiological examination.

\section{Microbiological processing}

Direct examination was not performed. Two serial 100fold dilutions were made and $0.1-\mathrm{mL}$ aliquots of the original suspension and each dilution were cultured. Each dilution and original suspension was placed on agar plates for aerobic and anaerobic culture. Bacterial identification and sensitivity tests were performed by standard methods [19]. Quantitative results of protected distal aspiration and lavage culture were expressed in colony forming units $\cdot \mathrm{mL}^{-1}\left(\mathrm{cfu} \cdot \mathrm{mL}^{-1}\right)$. Qualitative and quantitative cultures were evaluated by both techniques using various thresholds.

\section{Reference method}

Pneumonectomy was performed at the bedside within 30 min of death while maintaining mechanical ventilation. Depending on the predominant side of the radiographic infiltration, the right or left lung was removed via thoracotomy. If radiographic densities were diffuse, the right lung was removed. One specimen from each lobe (corresponding to an average size of $2 \times 2 \times 2 \mathrm{~cm}$ each), from suspicious areas if present, was cut superficially to avoid bronchial contamination.

When total lung removal could not be performed, open lung biopsies were used to sample the lung parenchyma. A 2-cm lateral thoracotomy incision was made in the fifth intercostal space. A rib spreader and atraumatic graspers were used. One to four biopsy specimens were taken blindly from dependent areas of one or several lobes. Bilateral biopsies were performed if radiographs showed bilateral infiltrates. Specimens were collected aseptically, weighed, and homogenized in peptone broth to obtain a final dilution of $1: 10$. Serial ten-fold dilutions $\left(1 \times 10^{-2}-\right.$ $1 \times 10^{-6}$ ) of this material were made and cultured. All bacteria cultured from lung tissue were taken into account whatever the number of colonies.

Histological examination of biopsies or entire lung was performed by an experienced pathologist (LG) with no prior knowledge of the culture results or clinical picture.

\section{Diagnosis of ventilator-associated bacterial pneumonia}

Both histological and histologically plus microbiologically-proven ventilator-associated bacterial pneumonia were assessed. Classification of histological pneumonia was determined according to the three grades of severity described by Rouby et al. [14] (focal bronchopneumonia, confluent bronchopneumoia, and lung abscess). Classification of each segment was based on the worst grade observed in that segment. Bronchiolitis was not considered as pneumonia. Histological plus microbiological ventilator-associated bacterial pneumonia was diagnosed by the presence of histological signs of ventilatorassociated bacterial pneumonia together with a positive culture of lung parenchyma.

\section{Statistical analysis}

All data are expressed as mean \pm standard deviation (SD). Depending on the size of the sample, chi-squared test with Yates correction or Fisher's exact test was used to compare qualitative data. The diagnostic yield of each sampling technique was assessed at different thresholds for the diagnosis of histological pneumonia by calculating the sensitivity, specificity, predictive values, false positive and false negative rates and diagnostic accuracy rate using 
standard formulae. The predictive performance of each procedure was evaluated by calculating the area under the Receiver Operator Characteristic (ROC) curve. The area under the ROC curve provides the best index of detectability or discrimination independent of the threshold value [20]. The different areas under the ROC curves were compared using the method described by HANLEY and McNeIL [20]. A p-value $<0.05$ was considered significant. The degree of concordance between protected distal aspiration and mini-bronchoalveolar lavage was assessed using Kappa coeficients. Kappa values close to 1.0 indicate a high degree of concordance between two methods while values under 0.40 indicate weak or no concordance [21].

\section{Results}

\section{Characteristics of the patients}

During the two study periods, 140 patients died after at least $72 \mathrm{~h}$ of mechanical ventilation in the ICU. Of these 140, 27 fulfilled the inclusion criteria and were included in the study (12 females and 15 males; mean age $66 \pm 10 \mathrm{yrs}$ ). Histological findings identified 14 patients with and 13 without ventilator-associated bacterial pneumonia. None of the variables or scores recorded on admission differed between the 2 groups except for the clinical suspicion of ventilator-associated bacterial pneumonia in the $24 \mathrm{~h}$ preceding death (table 1).

No patient other than number 25 had a change of antibiotic treatment during the three days preceding death (table 2). Fourteen patients had no intravenous antibiotics during the three days before death. Thirteen patients were still receiving antibacterial treatment in the final $24 \mathrm{~h}$ (table 2).

Table 1. - Clinical characteristics of the population studied

\begin{tabular}{|c|c|c|c|}
\hline & Pneumonia & $\begin{array}{c}\text { No } \\
\text { pneumonia }\end{array}$ & P-value \\
\hline Subjects $n$ & 14 & 13 & \\
\hline Age yrs & $61.8 \pm 8.8$ & $69.3 \pm 10.8$ & NS \\
\hline Sex M/F & $8 / 6$ & $7 / 6$ & NS \\
\hline $\begin{array}{l}\text { Reason for admission to } \\
\text { the ICU }\end{array}$ & & & NS \\
\hline Postsurgical status & 7 & 2 & NS \\
\hline $\begin{array}{l}\text { Neurological disorder } \\
\text { Acute exacerbation of }\end{array}$ & 3 & 4 & NS \\
\hline COPD & 2 & 3 & NS \\
\hline Lung contusion & 1 & 0 & NS \\
\hline Cardiac insufficiency & 1 & 3 & $<0.05$ \\
\hline Septic shock & 0 & 1 & NS \\
\hline APACHE II on admission & $21.4 \pm 6.1$ & $24.8 \pm 6.6$ & NS \\
\hline $\begin{array}{l}\text { Prior mechanical ventila- } \\
\text { tion days }\end{array}$ & $16 \pm 10$ & $22 \pm 21$ & NS \\
\hline CPIS* & $8.3 \pm 1.3$ & $5.4 \pm 2.4$ & $<0.01$ \\
\hline Complete clinical picture* & 14 & 5 & $<0.05$ \\
\hline${\mathrm{Pa}, \mathrm{O}_{2} / \mathrm{Fi}, \mathrm{O} 2 \mathrm{mmHg} *}^{*}$ & $148 \pm 15$ & $165 \pm 73$ & NS \\
\hline WBC $1 \times 10^{9} \cdot \mathrm{L}^{-1 *}$ & $17.6 \pm 8.8$ & $14.5 \pm 6.8$ & NS \\
\hline Body temperature ${ }^{\circ} \mathrm{C}^{*}$ & $38.7 \pm 1.0$ & $38.1 \pm 2$ & NS \\
\hline Radiographic score* & $8.1 \pm 2.2$ & $7.9 \pm 2.1$ & NS \\
\hline
\end{tabular}

Results presented as mean \pm SD. COPD: chronic obstructive pulmonary disease; CPIS: clinical pulmonary infection score; $\mathrm{Pa}_{\mathrm{a}} \mathrm{O}_{2}$ : oxygen tension in arterial blood: $\mathrm{Fi}, \mathrm{O} 2$ : inspiratory oxygen fraction; WBC: white blood cells. *: recorded prospectively in the 24 hours preceding death.
A total of five patients had previously had ventilatorassociated bacterial pneumonia diagnosed by clinical and microbiological criteria. In four of them this had been resolved at the time of the death (they had completed antibiotic treatment and showed clinical resolution and negative bronchial samples at least 3 days before the protocol: patients number: 10, 20, 21 and 24). The remaining patient had shown no real improvement despite antibiotics which were discontinued with the instruction "do not resuscitate" (patient number 16).

\section{Histological examination}

Histological analysis of the lung parenchyma was performed in 27 patients. The whole lung was examined in 20 cases, bilateral biopsies in 4 cases and unilateral biopsies in

Table 2. - Clinical status and management of patients

\begin{tabular}{|c|c|c|c|c|c|}
\hline Patient & $\begin{array}{c}\text { Duration } \\
\text { of } \mathrm{MV}\end{array}$ & $\begin{array}{l}\text { Previous } \\
\text { VABP } \\
\text { days since } \\
\text { diagnosis }\end{array}$ & CPIS & $\begin{array}{l}\text { Antibiotics } \\
* \text { (days) }\end{array}$ & $\begin{array}{l}\text { Indication } \\
\text { for current } \\
\text { antibiotics }\end{array}$ \\
\hline 1 & 11 & - & 8 & off (3) & \\
\hline 2 & 8 & - & 6 & on (4) & $\begin{array}{l}\text { suspicion } \\
\text { of VABP }\end{array}$ \\
\hline 3 & 14 & - & 8 & on (14) & meningitis \\
\hline 4 & 10 & - & 9 & on (8) & $\begin{array}{l}\text { suspicion } \\
\text { of VABP }\end{array}$ \\
\hline 5 & 14 & - & 9 & on (14) & aspiration \\
\hline 6 & 13 & - & 9 & off & \\
\hline 7 & 3 & - & 3 & off & \\
\hline 8 & 56 & - & 4 & off (18) & \\
\hline 9 & 29 & - & 9 & on (6) & $\begin{array}{l}\text { suspicion } \\
\text { of VABP }\end{array}$ \\
\hline 10 & 76 & $+(30$ days $)$ & 5 & off $(5)$ & \\
\hline 11 & 17 & - & 4 & on (11) & $\begin{array}{l}\text { Community- } \\
\text { acquired } \\
\text { pneumonia }\end{array}$ \\
\hline 12 & 26 & - & 3 & off (7) & \\
\hline 13 & 13 & - & 8 & on (12) & peritonitis \\
\hline 14 & 22 & - & 5 & off (3) & \\
\hline 15 & 15 & - & 7 & off (14) & \\
\hline 16 & 33 & + (27 days) & 6 & off (12) & \\
\hline 17 & 6 & - & 9 & off (3) & \\
\hline 18 & 8 & - & 5 & on (5) & aspiration \\
\hline 19 & 12 & - & 5 & off (7) & \\
\hline 20 & 13 & + (30 days) & 5 & off (7) & \\
\hline 21 & 21 & $+(17$ days $)$ & 8 & off (5) & \\
\hline 22 & 4 & - & 7 & on (4) & $\begin{array}{l}\text { suspicion } \\
\text { of VABP }\end{array}$ \\
\hline 23 & 7 & - & 11 & on (7) & $\begin{array}{l}\text { community- } \\
\text { acquired } \\
\text { pneumonia }\end{array}$ \\
\hline 24 & 35 & $+(25$ days $)$ & 8 & on $(8)$ & $\begin{array}{l}\text { gastric } \\
\text { paresis }\end{array}$ \\
\hline 25 & 12 & - & 3 & on (1) & $\begin{array}{l}\text { digestive } \\
\text { fistula }\end{array}$ \\
\hline 26 & 13 & - & 10 & off (6) & \\
\hline 27 & 20 & - & 8 & on (12) & bacteremia \\
\hline
\end{tabular}

*: Antibiotics used during the last 24 hours, (duration of antibacterial treatment if "on" and number of days without antibiotics if "off"). VABP: ventilator-associated bacterial pneumonia; MV: mechanical ventilation; CPIS: Clinical Pulmonary Infection Score calculated during the 24-h period preceding death. 
3 cases (right side). Histological examination of the parenchyma showed signs of pneumonia in 14 patients $(52 \%)$. Confluent bronchopneumonia was identified in seven of these 14 cases, focal bronchopneumonia in five and the remaining two patients had lung abscess. Both histology and tissue culture were positive in nine cases (table 3 ).

Table 3. - Lung and sampling technique culture results and histological grading

\begin{tabular}{|c|c|c|c|c|c|}
\hline Patient & $\begin{array}{c}\text { Micro- } \\
\text { organisms }\end{array}$ & $\begin{array}{l}\text { Protected } \\
\text { distal } \\
\text { aspiration } \\
\mathrm{cfu} \cdot \mathrm{mL}^{-1}\end{array}$ & $\begin{array}{l}\text { Mini- } \\
\text { broncho- } \\
\text { alveolar } \\
\text { lavage } \\
\mathrm{cfu} \cdot \mathrm{mL}^{-1}\end{array}$ & $\begin{array}{l}\text { Biopsy } \\
\mathrm{cfu} \cdot \mathrm{g}^{-1}\end{array}$ & $\begin{array}{l}\text { Histo- } \\
\text { logical } \\
\text { grading }\end{array}$ \\
\hline \multirow[t]{2}{*}{1} & $\begin{array}{l}\text { Pseudomonas } \\
\text { aeruginosa }\end{array}$ & $1 \times 10^{3}$ & $1 \times 10^{3}$ & 20 & \multirow[t]{2}{*}{$\begin{array}{c}\text { Confluent } \\
\text { BP }\end{array}$} \\
\hline & $\begin{array}{l}\text { Klebsiella } \\
\text { pneumoniae }\end{array}$ & $1 \times 10^{2}$ & $1 \times 10^{2}$ & - & \\
\hline 2 & - & - & - & - & - \\
\hline 3 & $\begin{array}{l}\text { Pseudomonas } \\
\text { aeruginosa }\end{array}$ & $1 \times 10^{2}$ & - & - & $\begin{array}{c}\text { Focal } \\
\text { BP }\end{array}$ \\
\hline 4 & - & - & - & - & $\begin{array}{l}\text { Focal } \\
\text { BP }\end{array}$ \\
\hline 5 & - & - & - & - & - \\
\hline 6 & $\begin{array}{l}\text { Staphylococ- } \\
\text { cus aureus }\end{array}$ & $1 \times 10^{5}$ & $1 \times 10^{4}$ & $2 \times 10^{2}$ & $\begin{array}{l}\text { Confluent } \\
\text { BP }\end{array}$ \\
\hline 7 & $\begin{array}{l}\text { Enterobacter } \\
\text { cloacae }\end{array}$ & - & $1 \times 10^{2}$ & - & - \\
\hline 8 & - & - & - & - & - \\
\hline 9 & $\begin{array}{l}\text { Enterococcus } \\
\text { faecalis }\end{array}$ & $1 \times 10^{4}$ & $1 \times 10^{5}$ & $2 \times 10^{3}$ & $\begin{array}{l}\text { Lung } \\
\text { abscess }\end{array}$ \\
\hline 10 & - & - & - & - & - \\
\hline 11 & - & - & - & - & - \\
\hline 12 & - & - & - & - & - \\
\hline 13 & Acinetobacter & $1 \times 10^{2}$ & $1 \times 10^{3}$ & - & - \\
\hline 14 & - & - & - & - & - \\
\hline 15 & $\begin{array}{l}\text { Klebsiella } \\
\text { pneumoniae }\end{array}$ & - & - & $2 \times 10^{3}$ & $\begin{array}{l}\text { Lung } \\
\text { abscess }\end{array}$ \\
\hline 16 & - & - & - & - & $\begin{array}{c}\text { Focal } \\
\text { BP }\end{array}$ \\
\hline 17 & $\begin{array}{l}\text { Staphyloccus } \\
\text { aureus }\end{array}$ & $1 \times 10^{4}$ & $1 \times 10^{6}$ & $1 \times 10^{4}$ & $\begin{array}{l}\text { Confluent } \\
\text { BP }\end{array}$ \\
\hline 18 & - & - & - & - & - \\
\hline 19 & $\begin{array}{l}\text { Enterobacter } \\
\text { aerogenes }\end{array}$ & $5 \times 10^{2}$ & $1 \times 10^{6}$ & 30 & - \\
\hline 20 & - & - & - & - & - \\
\hline 21 & $\begin{array}{l}\text { Enterobacter } \\
\text { aerogenes }\end{array}$ & $1 \times 10^{3}$ & - & + & $\begin{array}{c}\text { Confluent } \\
\text { BP }\end{array}$ \\
\hline 22 & - & - & - & - & $\begin{array}{l}\text { Focal } \\
\text { BP }\end{array}$ \\
\hline 23 & $\begin{array}{l}\text { Staphyloccus } \\
\text { aureus }\end{array}$ & $1 \times 10^{3}$ & - & - & $\begin{array}{c}\text { Focal } \\
\text { BP }\end{array}$ \\
\hline & $\begin{array}{l}\text { Staphyloccus } \\
\text { epidermidis }\end{array}$ & $1 \times 10^{3}$ & 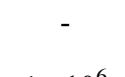 & - & \\
\hline 24 & $\begin{array}{l}\text { Pseudomonas } \\
\text { aeruginosa }\end{array}$ & $1 \times 10^{3}$ & $1 \times 10^{6}$ & + & $\begin{array}{l}\text { Confluent } \\
\text { BP }\end{array}$ \\
\hline 25 & $\begin{array}{l}\text { Escherichia } \\
\text { coli }\end{array}$ & - & - & + & - \\
\hline 26 & $\begin{array}{l}\text { Pseudomonas } \\
\text { aeruginosa }\end{array}$ & $1 \times 10^{3}$ & $1 \times 10^{3}$ & + & $\begin{array}{l}\text { Confluent } \\
\text { BP }\end{array}$ \\
\hline & $\begin{array}{l}\text { Escherichia } \\
\text { coli }\end{array}$ & - & - & + & \\
\hline 27 & $\begin{array}{l}\text { Escherichia } \\
\text { coli }\end{array}$ & - & $1 \times 10^{4}$ & + & $\begin{array}{l}\text { Confluent } \\
\text { BP }\end{array}$ \\
\hline
\end{tabular}

BP: bronchopneumonia; cfu: colony forming units.
Diagnostic performance of protected distal aspiration cultures

A total of 13 bacteria were detected in cultures obtained from protected distal aspiration samples. If only histological diagnosis was considered, the optimal threshold was $1 \times 10^{3} \mathrm{cfu} \cdot \mathrm{mL}^{-1}$ but this did not provide markedly better diagnostic accuracy when compared to qualitative analysis (table 4). Counts were $\geq 1 \times 10^{3} \mathrm{cfu} \cdot \mathrm{mL}^{-1}$ for nine bacteria, of which seven were also recovered from the lung parenchyma. When histological evidence was combined with a positive culture of the lung to define ventilatorassociated bacterial pneumonia, the sensitivity and specificity of protected distal aspiration at $1 \times 10^{3}$ $\mathrm{cfu} \cdot \mathrm{mL}^{-1}$ were $78 \%$ and $100 \%$, respectively.

\section{Diagnostic performance of mini-bronchoalveolar lavage cultures}

Eleven bacteria were isolated from cultures of minibronchoalveolar lavage in the 27 patients. Lavage cultures identified all but three bacteria isolated from the lung cultures and also showed three bacteria that were not present in the lung culture. Counts were $\geq 1 \times 10^{3} \mathrm{cfu} \cdot \mathrm{mL}^{-1}$ for nine bacteria, eight of which were also present in lung parenchyma. The optimal threshold for the diagnosis of histological pneumonia was $1 \times 10^{3} \mathrm{cfu} \cdot \mathrm{mL}^{-1}$ but this did not provide markedly better diagnostic accuracy when compared to qualitative analysis (table 4). When histological evidence and positive lung tissue culture were combined to define ventilator-associated bacterial pneumonia, the sensitivity of mini-bronchoalveolar lavage at the threshold of $1 \times 10^{3} \mathrm{cfu} \cdot \mathrm{mL}^{-1}$ was $78 \%$ and the specificity was $86 \%$.

\section{Comparison of the two sampling techniques}

No significant difference in sensitivity was observed between protected distal aspiration and mini-bronchoalveolar lavage, whatever the threshold considered (table 4). The concordance between the two techniques was excellent at $1 \times 10^{2}, 1 \times 10^{3}$ and $1 \times 10^{4} \mathrm{cfu} \cdot \mathrm{mL}^{-1}(\mathrm{k}$ coefficient, $0.78,0.74$ and 0.83 respectively). The area under the ROC curve for protected distal aspiration was greater than for lavage but the difference was not statistically significant (fig. 1).

Previous antibiotic therapy and diagnostic performance of protected distal aspiration and mini-bronchoalveolar lavage

Eight patients were being treated with antibiotics at the time of study due to a condition still being present (ventilator-associated bacterial pneumonia, communityacquired pneumonia or aspiration). In seven of these eight patients, protected distal aspiration and mini-bronchoalveolar lavage were concordant. In five of these seven cases the results were concordant with those of histology. When all patients receiving antibiotics during the three days preceding death were considered, the specificity of both techniques was unchanged. However, there was a slight 
Table 4. - Operative indices of protected distal aspiration and mini-bronchoalveolar lavage for the diagnosis of histological ventilator-associated bacterial pneumonia

\begin{tabular}{|c|c|c|c|c|c|c|c|}
\hline & Sensitivity & Specificity & $\begin{array}{c}\text { False positive } \\
\text { rate }\end{array}$ & $\begin{array}{c}\text { False negative } \\
\text { rate }\end{array}$ & $\begin{array}{c}\text { Positive } \\
\text { predictive value }\end{array}$ & $\begin{array}{c}\text { Negative } \\
\text { predictive value }\end{array}$ & Accuracy \\
\hline \multicolumn{8}{|c|}{ Protected distal aspiration } \\
\hline Qualitative $\mathrm{cfu} \cdot \mathrm{mL}^{-1}$ & 64 & 86 & 14 & 36 & 82 & 69 & 74 \\
\hline$\geq 1 \times 10^{2}$ & 64 & 86 & 14 & 36 & 82 & 69 & 74 \\
\hline$\geq 1 \times 10^{3}$ & 57 & 100 & 0 & 43 & 100 & 68 & 78 \\
\hline$\geq 1 \times 10^{4}$ & 21 & 100 & 0 & 79 & 100 & 54 & 59 \\
\hline$\geq 1 \times 10^{5}$ & 7 & 100 & 0 & 93 & 100 & 50 & 52 \\
\hline \multicolumn{8}{|c|}{ Mini-bronchoalveolar lavage } \\
\hline Qualitativecfu $\cdot \mathrm{mL}^{-1}$ & 50 & 77 & 23 & 50 & 70 & 59 & 63 \\
\hline$\geq 1 \times 10^{2}$ & 50 & 77 & 23 & 50 & 70 & 59 & 63 \\
\hline$\geq 1 \times 10^{3}$ & 50 & 86 & 14 & 50 & 78 & 61 & 67 \\
\hline$\geq 1 \times 10^{4}$ & 36 & 92 & 8 & 64 & 83 & 57 & 63 \\
\hline$\geq 1 \times 10^{5}$ & 21 & 92 & 8 & 69 & 75 & 52 & 56 \\
\hline
\end{tabular}

Data are presented as per cent (\%) (13 patients without pneumonia and 14 patients with pneumonia).

but nonsignificant decrease in sensitivity of protected distal aspiration for the diagnosis of histological ventilatorassociated bacterial pneumonia in patients receiving antibiotics as compared with those not receiving antibiotics during the three days preceding death (71\% and $43 \%)$. The sensitivity of mini-bronchoalveolar lavage was unaffected by the presence or absence of antibiotic therapy ( $57 \%$ and $43 \%)$.

Previous histological lung lesions and diagnostic performance of protected distal aspiration and minibronchoalveolar lavage

Eight patients had previously had ventilator-associated bacterial pneumonia (numbers: 10, 16, 20, 21 and 24) or aspiration pneumonia (numbers: 5,15 and 26), episodes which were different from those at the time of study. Histology showed bacterial pneumonia in five of these. Finally, histology was concordant with protected distal aspiration and mini-bronchoalveolar lavage findings in seven and six cases $(88 \%$ and $75 \%$ ) respectively.

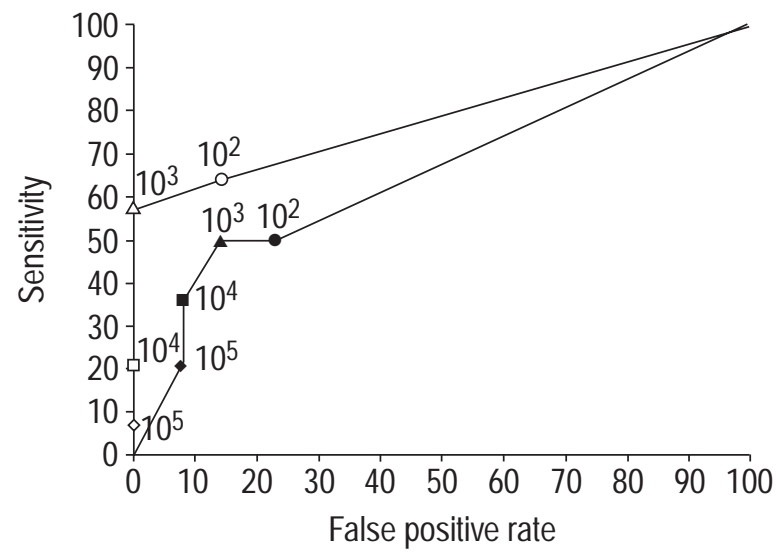

Fig. 1. - Receiver Operator Characteristic curves of protected distal aspiration $(\bigcirc ; \triangle ; \square ; \diamond)$ and mini-bronchoalveolar lavage $(\bigcirc ; \boldsymbol{\Delta} ; \mathbf{\square}$; -) for the diagnosis of histological ventilator-associated bacterial pneumonia. Each point on the curve indicates the sensitivity and 1specificity for a particular threshold: $1 \times 10^{2}: \bigcirc, \boldsymbol{O} ; 1 \times 10^{3}: \triangle, \boldsymbol{\Delta}$; $1 \times 10^{4}: \square$, $\mathbf{a}$; and $1 \times 10^{5}: \diamond, \diamond ; \mathrm{cfu} \cdot \mathrm{mL}^{-1}$.

\section{Clinical diagnosis}

All of the patients studied had at least two clinical criteria of suspected ventilator-associated bacterial pneumonia at the time of death. All of the 14 patients with histological evidence of pneumonia showed the complete clinical picture of pneumonia. This complete clinical picture was present in only five of the other 13 patients despite the fact that all satisfied the radiological criteria (table 2). The reason why 13 of the 19 patients showing the clinical picture of pneumonia did not receive new antibiotics was, a "do not resuscitate" decision in eight patients and the nonavailability of the results of sampling cultures performed during the 48-h period preceding death. Two additional patients (numbers 4 and 23) had been treated for a ventilator-associated bacterial pneumonia diagnosed 8 days previously and cultures performed in the final $48 \mathrm{~h}$ were not available at the time of death (table 2).

When compared with the histological diagnosis, the sensitivity and specificity of clinical judgement were $100 \%$ and $61 \%$ respectively. The CPIS was significantly higher in the pneumonia group. When a threshold of 6 was considered and compared with histological diagnosis, the sensitivity, specificity and diagnostic accuracy of the CPIS was $100 \%, 69 \%$ and $85 \%$ respectively.

\section{Discussion}

In the present study, the diagnostic performance of protected telescoping catheter sampling and its usefulness when using two different procedures (protected distal aspiration and mini-bronchoalveolar lavage) were evaluated prospectively in comparison with histology and lung tissue culture analysis for the diagnosis of ventilatorassociated bacterial pneumonia. The results show a very good concordance between the two techniques which were both specific and had good sensitivity in their ability to recover organisms from lung parenchyma.

Bronchoscopic methods used for the microbiological diagnosis of ventilator-associated bacterial pneumonia have several limitations: they are expensive, require specific equipment and qualified personnel, and should not be performed in the presence of severe hypoxaemia 
[22]. Their accuracy for the diagnosis of ventilatorassociated bacterial pneumonia has been challenged recently in several studies that also show that noninvasive blind methods can be as accurate [12, 23, 24]. Blind protected telescoping catheter avoids contamination by the upper tracheobronchial tree and thus could improve specificity in comparison with other blind methods. Nevertheless, to the best of the authors knowledge, protected telescoping catheter and its two sampling procedures, aspiration and lavage, have not been previously compared for the diagnosis of ventilator-associated bacterial pneumonia with histology as the reference test.

According to the well-demonstrated heterogeneity of the lung tissue bacterial burden $[5,9,25]$, the first Consensus Conference on the clinical investigation of ventilatorassociated bacterial pneumonia [26] recommended tissue examination and not culture for the evaluation of diagnostic techniques. Nevertheless, its must be kept in mind that a sampling technique is supposed to sample bacteria from the distal lung area. Therefore, protected telescoping catheter was evaluated in comparison with both histological ventilator-associated bacterial pneumonia and histological plus microbiological ventilator-associated bacterial pneumonia.

The use of antibiotic therapy is a real problem in evaluation of the diagnostic accuracy of microbiological methods as it should induce negative results. Most ICU patients receive antibiotics and it is difficult for ethical reasons to suspend antimicrobial treatment in premortem patients when clinically they are suspected of having ventilator-associated bacterial pneumonia. Despite the fact that in the present study eight patients were classified "do not resuscitate" and were off antibiotics, the role of antibiotics could not have been totally eliminated. However, they probably made only a minor contribution. Only five of the 14 patients with histological pneumonia had negative lung tissue culture but four of these five were receiving intravenous antibiotics at the time of study. It should be noted that one of these four patients had received intravenous antibiotics for 14 days because of meningitis (patient number 3). Therefore, the pathogens responsible for the recent pulmonary infection should have been resistant and growth should have been possible in culture (which was true for protected distal aspiration). The second patient treated with intravenous antibiotics had clinical signs of severe ventilator-associated bacterial pneumonia, suggesting a new episode that had developed despite antibiotic therapy, probably caused by resistant bacteria, and once again, available for culture. Two additional patients were being treated for a recent lung infection.

The results of the present study confirm those of RouBY and co-workers. [13, 14] for mini-bronchoalveolar lavage and give new information concerning protected distal aspiration. The study of PнAм et al. [12] which was performed to validate protected distal aspiration, had the advantage of targeting a large population of ventilated patients whose outcome was representative of ICUs $(51 \%$ survivors). Nevertheless, the reference diagnosis in this work was in part based on the results of the method that was evaluated (in association with the results of protected specimen brush cultures). Using such reference diagnosis, the authors reported a sensitivity of $100 \%$ and a specificity of at least $88 \%$ when protected distal aspiration showed at least one micro-organism at a concentration of $\geq 1 \times 10^{3} \mathrm{cfu} \cdot \mathrm{mL}^{-1}$. Considering the number of false negatives related to protected specimen brushing, the sensitivity of protected distal aspiration should have been overestimated in their work. With histological plus bacteriological reference, a sensitivity of $78 \%$ was found at the same threshold. The data in the present study, on the specificity at this threshold is in agreement with the above authors $(83-100 \%)$.

Clinical diagnosis is commonly inaccurate in recognizing ventilator-associated bacterial pneumonia [3, 27, 28]. In the present work, all of the 14 patients with histologically proven ventilator-associated bacterial pneumonia showed the complete clinical picture of ventilatorassociated bacterial pneumonia before death compared with five of the 13 patients without histological evidence. The low specificity limits the value of clinical criteria alone and treatment should be guided by culture results.

\section{Conclusions}

Using a histological post-mortem method, the results showed that protected telescoping catheter can be of diagnostic value for bacterial pneumonia acquired in ventilated patients. It has high specificity which is not the case when clinical judgment alone is used. For some clinicians, specificity is of major importance as it can limit antibiotic misuse which has an economic and ecological impact. Therefore, the technique could be proposed as an alternative to protected specimen brushing and bronchoalveolar lavage performed under fibrescopy. Moreover, it could be performed in addition to a less specific sampling technique such as endotracheal aspirate. This could be especially useful when a positive $\left(\geq 1 \times 10^{4}-1 \times 106\right.$ cfu $\cdot \mathrm{mL}^{-1}$ ) endotracheal aspirate is associated with an incoplete clinical picture.

\footnotetext{
Acknowledgements. The authors gratefully acknowledge C. Brun-Buisson for his suggestions
} for the redaction of this manuscript.

\section{References}

1. Salata RA, Lederman MM, Shlaes DM, et al. Diagnosis of nosocomial pneumonia in intubated, intensive care unit patients. Am Rev Respir Dis 1987; 135: 326-332.

2. Langer M, Mosconi P, Cigada M, Mandelli M, Tognoni G and ICUGIC. Long term respiratory support and risk of pneumonia in critically ill patients. Am Rev Respir Dis 1989; 140: 302-305.

3. Torres A, El-Ebiary M, Padro L, et al. Validation of different techniques for the diagnosis of ventilatorassociated bacterial pneumonia. Comparison with immediate postmortem pulmonary biopsy. Am J Respir Crit Care Med 1994; 149: 324-331.

4. Kollef MH, Silver P, Murphy DM, Trovillion E. The effect of late-onset ventilator associated pneumonia in determining patient mortality. Chest 1995; 108: 16551662.

5. Fabregas N, Torres A, El-Ebiarm, et al. Histopathologic 
and microbiologic aspects of ventilator-associated bacterial pneumonia. Anesthesiology 1996; 84: 757-759.

6. Marquette $\mathrm{CH}$, Copin M-C, Wallet F, et al. Diagnostic tests for pneumonia in ventilated patients: prospective evaluation of diagnostic accuracy using histology as a diagnostic gold standard. Am Rev Respir Dis 1995; 151: 1878-1888.

7. Chastre J, Viau F, Brun P, et al. Prospective evaluation of the protected specimen brush for the diagnosis of pulmonary infections in ventilated patients. Am Rev Respir Dis 1984; 130: 924-929.

8. Chastre J, Fagon JY, Soler P, et al. Diagnosis of nosocomial bacterial pneumonia in intubated patients undergoing ventilation: comparison of the usefulness of bronchoalveolar lavage and the protected specimen brush. Am J Med 1988; 85: 499-506.

9. Papazian L, Thomas P, Garbe L, et al. Bronchoscopic or blind bronchial sampling techniques for the diagnosis of ventilator-associated bacterial pneumonia. Am J Respir Crit Care Med 1995; 152: 1982-1991.

10. Niederman MS, Torres A, Summer W. Invasive diagnostic testing is not needed routinely to manage suspected ventilator-associated bacterial pneumonia. $\mathrm{Am}$ J Respir Crit Care Med 1994; 150: 565-569.

11. Chastre J, Fagon JY, Trouillet JL. Diagnosis and treatment of nosocomial pneumonia in patients in intensive care units. Clin Infect Dis 1995; 21 (Suppl. 3): S226-S237.

12. Pham LH, Brun-Buisson C, Legrand P, et al. Diagnosis of nosocomial bronchopneumonia in mechanically ventilated patients. Comparison of a plugged telescoping catheter with the protected specimen brush. Am Rev Respir Dis 1991; 143: 1055-1061.

13. Rouby JJ, Rossignon $\mathrm{MD}$, Nicolas $\mathrm{MH}$, et al. A prospective study of protected bronchoalveolar lavage in the diagnosis of nosocomial pneumonia. Anesthesiology 1989; 71: 79-85.

14. Rouby JJ, Martin De Lassale E, Poete $\mathrm{P}$, et al. Nosocomial bronchopneumonia in the critically ill. $\mathrm{Am}$ Rev Respir Dis 1992; 46: 1059-1066.

15. Knaus WA, Draper EA, Wagner DP, Zimmerman JE. APACHE II: a severity of diseases classification system. Crit Care Med 1985; 13: 818-829.

16. McCabe WR, Jackson GG. Gram-negative bacteremia. Etiology and ecology. Arch Intern Med 1962; 110: 847864.

17. Weinberg PF, Matthay MA, Webster RO, Roskos KV,
Goldstein IM, Murray JF. Biologically active products of complement on acute lung injury in patients with the sepsis syndrome. Am Rev Respir Dis 1984; 130: 791796.

18. Pugin J, Auckenthaler R, Mili N, et al. Diagnosis of ventilator-associated bacterial pneumonia by bacteriologic analysis of bronchoscopic and nonbronchoscopic "blind" bronchoalveolar lavage fluid. Am Rev Respir Dis 1991; 143: 1121-1129.

19. Lennette EH, Balows A, Hausler WJ Jr, Truand JP. Manual of Clinical Microbiology. 3rd ed. Washington DC, American Society for Microbiology, 1982.

20. Hanley JA, McNeil BJ. A method comparing the areas under receiving operating characteristic curves derived from the same cases. Radiology 1983; 148: 839-843.

21. Cohen J. A coefficient of agreement for nominal scales. Educ Psychol Measmt 1960; 20: 37-46.

22. Papazian L, Colt HG, Scemama F, Martin C, Gouin F. Effects of consecutive, protected, specimen brushing and bronchoalveolar lavage on gas exchange and hemodynamics in ventilated patients. Chest $1993 ; 104,1548-$ 1552.

23. Leal-Noval SR, Alfaro-Rodriguez E, Murillo-Cabeza F, Garnacho-Montero J, Rey-Perez J, Munoz-Sanchez MA. Diagnostic value of the blind brush in mechanically ventilated patients with nosocomial pneumonia. Intensive Care Med 1992; 18: 410-414.

24. Papazian L, Martin C, Meric B, Dumon JF, Gouin F. A reappraisal of blind bronchial sampling in the microbiologic diagnosis of nosocomial bronchopneumonia. Chest 1993; 103: 236-242.

25. Kirtland SH, Corley DE, Winterbauer RH, et al. The diagnosis of ventilator-associated pneumonia. A comparison of histologic, microbiologic and clinical criteria. Chest 1997; 112: 445-457.

26. Pingleton SK, Fagon J-Y, Leeper KV. Patient selection for clinical investigation of ventilator-associated bacterial pneumonia. Criteria for evaluating diagnostic technique. Chest 1992; 102 (Suppl): 553S-556S.

27. Andrews CP, Coalson JJ, Smith JD, Johanson WG. Diagnosis of nosocomial bacterial pneumonia in acute, diffuse lung injury. Chest 1981; 80: 254-258.

28. Fagon J-Y, Chastre J, Hance AJ, Domart Y, Trouillet J-L, Gibert C. Evaluation of clinical judgement in the identification and treatment of nosocomial pneumonia. Chest 1993; 103: 547-553. 